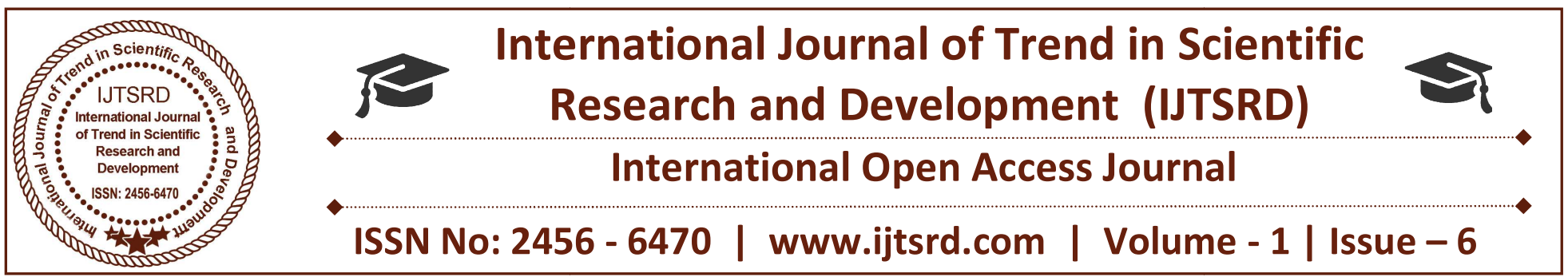

\title{
Histopathological Studies on the effect of Sodium Fluoride on the fertility of Male Albino Rat
}

\author{
Dr.Smita Tiwari \\ P.G.Department of Zoology \\ P.D.B.H., Govt.(P.G.) College, Kotdwar \\ HNB, Garhwal University (A Central University), Uttarakhand, India
}

\begin{abstract}
The effect of chronic exposure of Sodium Fluoride $(\mathrm{NaF}), \quad(5,20,50 \mathrm{mg} / \mathrm{kg}$ b.w.) for 60days, on reproductive tissue damage in young male albino rat was evaluated histopathologicaly along with certain genital tissue wet weight . Damaging effect on testicular histoarchitecture along with disfigured tubular structure was recorded alongwith histological change in other organs viz.- Epididymis , vasdeference seminal vesicle, and prostate gland . Even the epermatogenesis seemed to be arrested and clumping of spermatozoa was also obsorbed. The said effect were not observed in the control group.
\end{abstract}

Keywords: Albino rat, Fluoride, antifertility effects, reproductive organs.

\section{INTRODUCTION}

Many of the states of the Indian union (Table1) have alarmingly high concertrations of fluoride in their water resources (ICMR 1975, Choubisa 2001; Mishra and Mishra 2006). The situation in Gujrat in India is not different from that of the rest of the country. Excessive intake of fluoride leads to serious effects on the teeth during tooth formation and abnormal hardening of bones, leading to a condition known as fluorosis that is exacerbated by poor diets deficient in calcium and vitamins.

Surface water seldom has fluoride in excess of 0.3 $\mathrm{mg} / \mathrm{L}$. Ground water sources such as dug wells, shallow and deep hand pumps and especially tube

well may contain excess fluoride where minerals like cryolite, biotile and fluorapatite are present. This is mainly due to the dissolution of fluoride from fluoride bearing minerals. About 96 percent of the fluoride in the body is found in bones and teeth. Fluoride is also essential for the normal mineralization of the bones and formation of dental enamel. Fluorite $\left(\mathrm{CaF}_{2}\right)$ is a source of industrial mineral and major source of fluoride contamination in water and soil. Fluorspar is commonly known as an ore of mineral fluorite. Fluorite/Fluorspar occur in many rocks in varied forms. Gujarat, Rajasthan and Madhaya Pradesh are the only fluorite producing states. In Gujarat, Amba Donger (Kadipani) in Chhota Udaipur taluka of Vadodara district is the principal producing region. The fluoride content of the rocks dure to repeated weathering gets slowly dissolved in water when the water acquires acidic nature. In this procedure, water gets contaminated by fluoride.

A permissible limit of fluoride concentration in drinking water as per WHO guidelines is up to 1.5 $\mathrm{mg} / \mathrm{L}$. The probable relationship between fluoride concentration in drinking water and its effects are given in Table 2. The excessive amount of fluoride in water and environment is poisonous. Fluoride endemic has been reported in several districts of 19 Indian states and Union territories. The affected population is 25 million and at least 15 Indian states (including Gujarat) have been identified as having excess fluoride in drinking water. 
Table 1. Percentage categories of fluorosis in various states of India

\begin{tabular}{|l|l|}
\hline \multicolumn{1}{|c|}{ Category and percentage } & \multicolumn{1}{c|}{ Names of states } \\
\hline I (30\% of the districts affected) & $\begin{array}{l}\text { Jammu and Kashmir,Delhi, Kerala and } \\
\text { Orissa }\end{array}$ \\
\hline II (30-50\% of the districts affected) & Maharashtra, Karnataka and Bihar \\
\hline III (50-100\% of the districts affected) & $\begin{array}{l}\text { Uttar Pradesh, Rajasthan Gujarat, Andhra } \\
\text { Pradesh and Tamil Nadu }\end{array}$ \\
\hline
\end{tabular}

Source: Susheela 1987; Susheela 1999 and Susheela 2007

Table 2 Effect of fluoride concentration

\begin{tabular}{|l|l|}
\hline \multicolumn{1}{|c|}{ Fluoride concentration $\mathrm{mg} / \mathrm{L}$} & \multicolumn{1}{c|}{ Effect } \\
\hline Less than 1.5 & No effect \\
\hline 1.5 to 3.0 & Dental Fluorosis \\
\hline 3.1 to 6.0 & Mild Skeletal Fluorosis \\
\hline More than 6.0 & Crippling Skeletal Fluorosis \\
\hline
\end{tabular}

\section{MATERIALS AND METHODS}

The study was conducted on adult male albino rats (Rattus rattus ), of average age 12-14 weeks and weighing 125-200grams. They were acclimatized to laboratory conditions for 15 days prior to the commencement of the treatment. The rats were kept in open air cages $(60 \times 45 \times 45 \mathrm{~cm})$ at room temperature (Edmond,1950) . The rats were fed standard rodent pellet (Hindustan Lever Ltd. ) and water was allowed ad libitum. After the treatment animals were sacrificed by cervical dislocation .

Test Chemicals- Sodium fluoride (ExcelaR) obtained from Qualigens Fine Chemicals, Mumbai was used.

\section{(a) Histopathological study}

\section{Experimental Design}

The rats were divided into the following four groups:

Group 1- Control, Group 2-4-Experimental: $5,20,50 \mathrm{mg} / \mathrm{kg} \mathrm{b.w}$. of sodium fluoride dissolved in $1 \mathrm{ml}$.of double distilled water/kg.b.w./ day were given orally for the 60 days. 5 rats in each group of $5 \mathrm{mg}$, $20 \mathrm{mg}$ and $50 \mathrm{mg}$ doses. Thereafter, they were sacrificed by cervical dislocation and reproductive organs were taken out, for histological studies.
The reproductive organs were removed and fixed in alcoholic Bouins Fluid. The tissues (Testes, Epididymis, Vas deferens, Seminal vesicle and Prostate) were washed in $70 \%$ alcohol and then dehydrated in alcholic series and embedded in paraffin wax, several sections were cut of 6 micron and stained with iron Hemotoxylin and Eosin for Histopathological examination. (McManus and Lowery, 1965)

After conducting the above experiment, histopathological studies were conducted by preparing the stained microtome slides. Histopathological studies were observed and compared with the control, under the NaF stress.

\section{(b) Body Weight and Organ Weights}

Final body weight of each animal was recorded on the day of sacrifice. Testis, Epididymis, vas deferens, Seminal vesicle and prostate were dissected out, and wet weights of these organs were measured by single pan electrical balance .

\section{Effect of Sodium Fluoride on the body weight and reproductive tissue wet weight in male rats.}


Table : 3

\begin{tabular}{|c|c|c|c|c|c|c|c|c|c|}
\hline $\begin{array}{l}\text { Treat } \\
\text { ment }\end{array}$ & $\begin{array}{c}\text { Dos } \\
\mathrm{e} \\
(\mathrm{mg} \\
/ \mathrm{kg}) \\
\end{array}$ & $\begin{array}{l}\text { Dura } \\
\text { tion } \\
\text { (Day } \\
\text { s) } \\
\end{array}$ & $\begin{array}{l}\text { Initial b.w. } \\
\text { (g) }\end{array}$ & $\begin{array}{l}\text { Final b.w. } \\
\text { (g) }\end{array}$ & Testis & Epididydmis & $\begin{array}{c}\text { Vas } \\
\text { Deference }\end{array}$ & $\begin{array}{l}\text { Seminal } \\
\text { Vesicle }\end{array}$ & Prostate \\
\hline Control & & 60 & $\begin{array}{ll}175.4 \quad \pm \\
1.20\end{array}$ & $\begin{array}{ll}182.20 \quad \pm \\
1.10\end{array}$ & $\begin{array}{l}920.73 \\
3.23 \\
\end{array}$ & $\begin{array}{l}370.39 \\
5.12\end{array}$ & $\begin{array}{ll}210.65 \quad \pm \\
2.49\end{array}$ & $\begin{array}{ll}287.10 & \pm \\
6.13 & \\
\end{array}$ & $\begin{array}{l}320.41 \\
6.30\end{array}$ \\
\hline $\begin{array}{l}\text { Sodiu } \\
\mathrm{m} \\
\text { fluorid } \\
\mathrm{e}\end{array}$ & 5 & 60 & $\begin{array}{ll}172.15 & \pm \\
1.55 & \end{array}$ & $\begin{array}{l}180.30 \\
2.15\end{array}$ & $\begin{array}{l}931.63 \\
2.52\end{array}$ & $\begin{array}{l}310.33 \\
1.14^{*}\end{array}$ & $\begin{array}{l}210.47 \\
2.29^{*}\end{array}$ & $\begin{array}{l}377.10 \\
5.67\end{array}$ & $\begin{array}{l}443.37 \\
3.01^{*}\end{array}$ \\
\hline Doses & 20 & 60 & $\begin{array}{ll}170.61 \quad \pm \\
6.30\end{array}$ & $\begin{array}{l}175.10 \\
1.25\end{array}$ & $\begin{array}{l}913.98 \\
2.79 *\end{array}$ & $\begin{array}{l}321.69 \\
5.39 *\end{array}$ & $\begin{array}{l}180.73 \\
1.52\end{array}$ & $\begin{array}{l}282.79 \\
5.20^{*}\end{array}$ & $\begin{array}{l}259.86 \\
4.20^{*}\end{array}$ \\
\hline & 50 & 60 & $\begin{array}{ll}165.10 \quad \pm \\
1.21\end{array}$ & $\begin{array}{l}170.10 \quad \pm \\
5.11\end{array}$ & $\begin{array}{ll}915.10 \quad \pm \\
4.31 *\end{array}$ & $\begin{array}{ll}271.21 & \pm \\
7.41 & \end{array}$ & $\begin{array}{ll}295.71 \quad \pm \\
0.61^{*}\end{array}$ & $\begin{array}{ll}301.10 \quad \pm \\
7.11\end{array}$ & $\begin{array}{l}375.61 \\
8.10\end{array}$ \\
\hline
\end{tabular}

$* * 60$ days of treatment values are mean \pm SE $(n=5) *$ denotes significance at $<5 \%$ level In each category -5 Rats/ Tissues were used.

\section{RESULTS}

\section{Anti-Fertility Studies:}

(i) Effect of Sodium Fluoride (NaF) on the body weight and on reproductive organ weight.

The results of the experiment are presented in table -3

\section{(ii) Sodium Fluoride (NaF) Doses}

Administration of $5 \mathrm{mg} / \mathrm{kg}$ of Sodium Fluoride $(\mathrm{NaF})$ for 60 days did not result in any change in the b.w. Treatment of rats with $20 \mathrm{mg} / \mathrm{kg}$ of $\mathrm{NaF}$ for 60days resulted in increasing body weight as compared to the control. Treatment of rats with $50 \mathrm{mg} / \mathrm{kg}$ of $\mathrm{NaF}$ for 60day resulted in increase in body weight as compared to the control group.

\section{Effect of Sodium Fluoride on histology of TESTES:}

\section{Control (Plate - 1)}

The transverse section of testis of the control rat consisted of highly expanded seminiferous tubules with germinal epithelium consisting of successive stages of germ cells such as primary spermatocytes, secondary spermatocytes, spermatids and spermatozoa. The sperms were present in large numbers and there disposition was typical . The interstitial spaces between the seminiferos tubules are filled with loose connective tissues made up of cells of leydig's and blood vessels . The rat showed normal behaviour and their was no mortality .

\section{Experimental group: 60 days-5mg/kg b.w.( Plate - 1a)}

Produced mild change in the histo-architecture of seminiferous tubules, as compared to 30 days picture of the same dose.

\section{Experimental group: 60 days $-20 \mathrm{mg} / \mathrm{kg}$ b.w.( Plate- $1 \mathrm{~b})$}

20mg. dose for a period of 60 days, the testicular histology was severely affected. The tubules presented disorganized germinal epithelium. Spermatozoa were absent while other cellular elements were degenerated and the vascularity was also poor.

Experimental group: 60 days $-50 \mathrm{mg} / \mathrm{kg}$ b.w.( Plate 1c)

50mg. dose for a period of 60 days, significant damaging effect on testicular histo-architecture was seen. The seminiferous tubules were disfigured and spermatogenesis seems to be arrested. In the higher 
dosage groups, spermatogenesis stopped and the seminiferous tubules became necrotic. The study established the existence of a definite relationship between fluorosis and testicular damage, however vascularity was observed to be poor.

\section{Effect of Sodium Fluoride on histology of EPIDIDYMLS:epididymis.}

\section{Control - Caput epididymis (Plate-2)}

The transverse section of Caput epididymis presented a normal histological picture. The epithelial cells of the caput were tall, columnar with nucleus arranged in a row, near the thin basement membrane. The segments of stereocilia were more profuse in the caput region than in the cauda.

\section{(ii) Control - Cauda epididymis (Plate-3)}

The epithelium of the cauda consisted of low cuboidal cells. The lumen of the ductules were larger in the cauda and smaller in the caput. Intertubular connective tissue and vascularity were observed to be normal in cauda and caput epididymis. Both the portions of the epididymis were full of spermatozoa .

Experimental group: 60 days $-5 \mathrm{mg} / \mathrm{kg}$ b.w.( Plate2a,3a)

Sodium fluoride $(\mathrm{NaF})$ administered to male rat of $5 \mathrm{mg} . / \mathrm{kg} . \mathrm{b} . \mathrm{w}$. for 60 days caused deterioration in histo-architecture .

Caput : (Plate-2a)

Decreased no. of sperms were found as compared to $5 \mathrm{mg} . / \mathrm{kg}$. b.w. in 30 days case.

\section{Cauda: (Plate-3a)}

In the higher dosage groups, spermatogenesis stopped and the tubules became necrotic.

\section{Experimental group: 60 days $-20 \mathrm{mg} / \mathrm{kg}$ b.w.( Plate-} 2b,3b)

\section{Caput: (Plate-2b)}

60 days $20 \mathrm{mg} . / \mathrm{kg}$. b.w. dose produced marked increase in the intertubular fibrosis .The epithelial cell height was reduced and nuclear pyknosis appeared amongst them the effect was more pronounced in the caput portion of the epididymis . Karyoloysis and the absence of spermatozoa were evident in some caput ductules.

\section{Cauda: (Plate-3b)}

Small amounts of spermatozoa were observed in the lumen of cauda but stereocilia were completely absent, exudates of unidentifiable cells were also present in the intertubular spaces of both the portions

Experimental group: 60 days $-50 \mathrm{mg} / \mathrm{kg}$ b.w.(Plate2c,3c)

\section{Caput :(Plate-2c)}

50mg./kg.b.w. dose for 60 days of treatment produced drastic histological changes in both the portions of the epididymis . In the caput, the tubules were deshaped and contained few spermatozoa. The epithelium was hypertrophical and cells presented dysplasia in the nuclear position. The intertubular spaces were filled with fibrotic tissues.

\section{Cauda:-(Plate-3c)}

In cauda (epididymis) the epithelial cell height was reduced. The nuclei of epithelial cells were pyknotic and epithelium at certain places were damaged. The intertubular spaces were slightly reduced and stereocilia were absent. Connective tissues hypoplasia was also evident .

\section{Effect of Sodium Fluoride on histology of VAS DEFERENS:}

\section{Control: - (Plate-4)}

The transverse sections of the vas deferens of control rats showed normal histological picture with three distinct muscular patterns, i.e. the outer longitudinal, middle circular and inner longitudinal layers. The lamina propria was present between the inner longitudinal muscle layer and the pseudostratified epithelium, which contained stereocilia. The epithelial cell layer was folded so as to form a stellate lumen in which the sperm bundles were present.

\section{Experimental group: 60 days-5mg/kg b.w.( Plate -} 4a)

Did not result in any observable changes in the histological features of vas deferens of treated animals. The lumen was filled with spermatozoa and the epithelial cell layers were folded so as to form a stellate lumen . 
Experimental group: 60 days-20mg/kg b.w.( Plate $-4 b)$

This experiment was observed to have induced mild changes in the histology of the vas deferens. The stellate form of lumen was distorted. The sperms were lacking in the lumen and vacuolation was observed in the middle circular muscle layer .

Experimental group: 60 days-50mg/kg b.w.( Plate $-4 c)$

50mg./kg.b.w. dose for 30 days caused marked degenerative changes in histology of the vas deferens. The luminal epithelium showed nuclear pyknosis. Few spermatozoa were observed in the lumen.In the vas deferens, the sperms revealed deflagellation and tail abnormalities. This is probably related to the alterations in the internal milieu of this organ which rendered the spermatozoa immotile and consequently caused fertility impairment in the experimental animals. Thus this dose of sodium fluoride, was found to affect reproductive function and fertility rate.

\section{Effect of Sodium Fluoride on histology of SEMINAL VESICLE}

\section{Control: (Plate-6)}

The transverse sections(T.S.) of seminal vesicle of control rats showed muscosal folds extending into the lumen. The lumen was filled with secretions produced by glandular epithelium . The epithelial lining of mucosa consisted of a single layer of tall columnar cells with basal oval nuclei. The lamina propria of the mucosa comprised of cellular connective tissues containing smooth muscle cells.

\section{Experimental group: 60 days-5mg/kg b.w.(Plate - 5a)}

5mg./kg.b.w. dose for 30 days produced no alterations in the histological structure of seminal vesicle. The epithelium was normal, comprising of single layer of tall columnar cells with basal nuclei.

Experimental group: 60 days-20mg/kg b.w.( Plate $-5 b)$

20mg./k.g. b.w dose for 30 days produced induced mild alterations in the histology of the seminal vesicle. Epithelial lining had a single layer of tall columnar cells with nuclei, the cryptic pattern of the epithelium was normal. The muscle layer surrounding the epithelium was very thick, the lamina propria had somewhat less vascularity as compared to control.

Experimental group: 60 days $-50 \mathrm{mg} / \mathrm{kg} \mathrm{b.w.(} \mathrm{Plate}$ $-5 c)$

50mg./k.g.b.w. dose for 60 days however caused alternation in the histology of seminal vesicle. The lumen had less secretion. The size of the lumen appeared to have reduced mainly due to lumenward manifestation of the epithelium. The epithelial cells had changed their shape and the muscular arrangement appeared to be damaged.

\section{Effect of Sodium Fluoride on histology of PROSTATE GLAND}

\section{Control: (Plate-7)}

The histological structure of the prostate gland in T.S. of control animals showed a number of alveoli lined by the low columnar epithelium with basal nuclei, the follicular lumen was full of secretions. There was an intervening fibromuscular stroma. The epithelium had proliferated into the crypts, having invaded lumen. Folding of the mucosal lining was observed in smaller tubules but distended tubules had no mucosal folds.

\section{Experimental group:60 days-5mg/kg b.w.(Plate - 6a)}

5mg./kg.b.w.dose for 30 days produced no histological changes in the prostate of the treated animals . The alveoli were lined with normal epithelium. The lumen was full of secretions.

\section{Experimental group:60 days-20mg/kg b.w.(Plate -} 6b)

However the lumen had less secretion. All other secretions showed usual pattern and the histological features appeared normal.

\section{Experimental group:60 days-50mg/kg b.w.(Plate - 6c)}

$50 \mathrm{mg} . / \mathrm{kg} . \mathrm{b} . \mathrm{w}$. dose for 30 days resulted in the reductions of the size of lumen and lowering of secrections. The cryptic structure of the prostate gland was found disturbed after the treatment.

\section{DISCUSSION}

The germinal ephithelium were disorganized and lacked spermatogonia. In the male albino rats, the completion of spermatogenic cycle requires 65 days of 
time (Jackson 1973), out of which first five days the differentiation and maturation takes place from spermatogonia to spermatozoa within the testes.

Dvoakova-Hortova et al. (2007) described the influence of fluorides on mouse sperm capacitation. Effect of long - term fluoride exposure on lipid peroxidation and histology of testes in first and second - generation rats is disecribed by Oncii et al. (2007).

Epididymal and ejaculated spermatozoa of a number of species also possessed enzymes capable of metabolizing steroids (Sheela Rani et al., 1978).

The histoarchitecture of proximal and distal vas deferens reveals that it is not a simple connection for sperm transport, but it is a vital organ for the maintenance of sperm structure, survival and viability (Chinoy, 1985; Rajalakshmi, 1985; Chinoy et al, 1977).

Gupta et al. (2007) found that fluoride treatment caused an significant decrease in the weight of testes, epididymis and ventral prostate. The sperm mortality and density were significantly reduced. Primary spermatocyte, secondary spermatocyte and spermatids had marked reduction. The sertoli cell count and their cross sectional surface areas were significantly reduced . Leydig's cell nuclear area and the number of mature leydig's cells were also significantly decreased. In conclusion, $\mathrm{NaF}$ administered in drinking water under chronic treatment of 2,4 and 6 ppm for 6 month to male rats adversely affected their fertility and reproductive system.

\section{REFERENCES}

1) Chinoy, N.J. 1985:Structure and physiology of mammalian vas deferens in relation to fertility regulation. J.Biosci., 7(2):215-221.

2) Choubisa SL.2001 Endemic fluorosis in southern Rajasthan, India, Fluoride 34:61-70.

3) Dvo akova-Hortova, K., Sandera, M., Jursova, M., Vasinova, J., Pknicova, J. 2007: The influence of fluorides on mouse sperm capacitation. Anim. Reprod. Sci. Epub ahead of print.

4) Edmond, J. F. 1950: The care and Breedings of laboratory animals. John Wiley and Sons Inc., New York. Compain and Hall Ltd. London.
5) Gupta, R. S., Khan, T.I., Agarwal, D. and Kachhawa, J.B.S. 2007: The toxic effect of sodium fluoride on the reproductive system of male rats. Toxicol. and Ind. Hlth., 23, 9:507-513.

6) Indian Council of Medical Research 'ICMR' 1975 New dimensions to fluorosis in Andhra Pradesh, 5:1-5.

7) Jackson, H. 1973: Chemical methods of male contraception. Am. Sci.,61(2): 188-193.

8) Mc Manus, J.F.A and Lowry , R.W. 1965 Staining methods histological and histochemical and histochemical. Herpo and Row, New York, Evaniston, London.

9) Mishra, A.K. and Mishra , A. 2006 Premaj. Escalation of groundwater fluoride in the Ganga alluvial plains of India. Fluoride 39:35-8.

10) NEFRI, Magpur, Defluoridation, 1992 p.61.

11) Oncii, M., Kocak, A., Karaoz, E., Darici, H., Savik, E., Gultekin, F. 2007: Effect of long - term fluride exporsure on lipid peroxidation and Histology of testes in first-and second- gentration rats. Biol. Trace. Elem. Res.118(3): 260- 8.

12) Rajalkshmi, M. 1985: Physiology of epididymis and spermatozoa. J.Biosci., 7(2):191-195.

13) Sheela Rani, C.S., Murty, G.S.R.C. and Moudgal, N.R. 1978: Effect of chronic neutralization of endogenous FSH on testicular function in the adult male bonnet monkey-assessment using biochemical parameters. Int.J.Androl., 1:489-500.

14) Susheela, A.K. 1987. Fluorosis in India, the magnitude and severity of the problem. Sci Dev Env. 147-157.

15) Susheela, A.K. 1999 Fluorosis management programme in India. Curr Sci 77:1250-1256.

16) Susheela, A.K. 2007. Fluorosis management programme in India Curr Sci 77:1250-1256. 


\section{EXPERIMENTAL GROUPS - 60 DAYS}

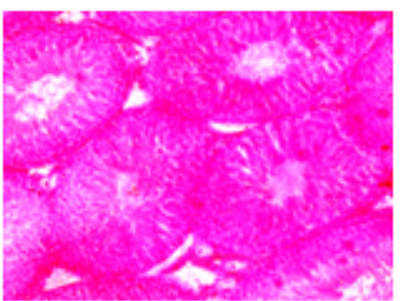

Control\# Plate 1

(Testes)

Photomicrograph

Showing T.S of Testes with expanded seminiferous tubules, with germinal epithelium including spermatocytes and

spermatids and spermatozoa . Interstitial space filled with loose connective tissues and blood vessels.

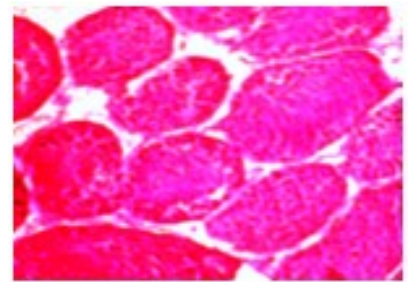

Plate\# 2 (EpididymisCaput)

Photomicrograph showing lumen of ductules, intertubular connective tissues and vascularity . Lumen of ductules are full of spermatozoa and stereocilia are present at the apices of the columnar cells having elongated nucleus .

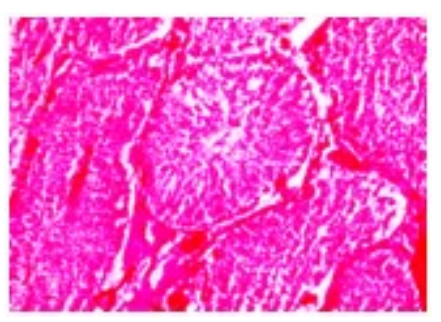

\section{Plate\# 1a- Testes $5 \mathrm{mg} / \mathrm{kg} \mathrm{b.w}$}

Photomicrograph showing germinal epithelium touching closely, with lesser spermatozoa. The connective tissues and blood vessels visible.

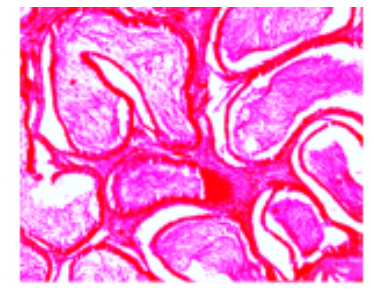

\section{Plate\# 2a-Epididymis} (Caput) 5mg/kg b.w. Photomicrograph showing shortened columnar cells, tubules deshaped . Epithelium is hypotrophied.

Intertubular spaces are filled with fibrotic tissues. Stereocilia are absent.

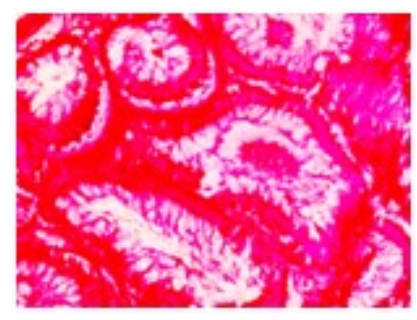

\section{Plate\# 1b- Testes 20mg/kg b.w}

Photomicrograph showing intermingling of the seminiferous tubules. The spermaogonia and spermatocytes found damaged.

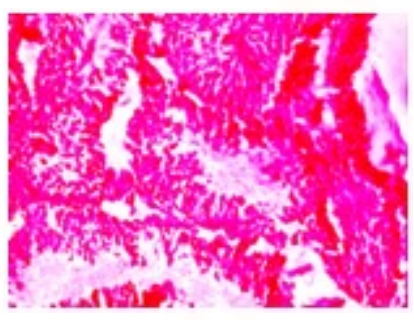

\section{Plate\# 1c- Testes $50 \mathrm{mg} / \mathrm{kg} \mathrm{b.w}$}

Photomicrograph showing disintegrated seminiferous tubules with damaged spermatogonia and spermatocytes having vacuoles made up of dissolved damaged cell debris.

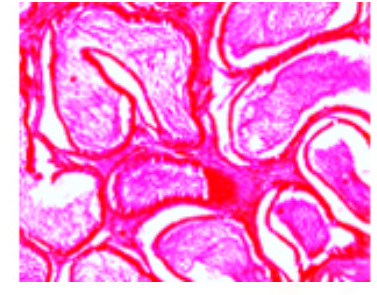

Plate\# 2b-Epididymis (Caput) 20mg/kg b.w. Photomicrograph showing lost cellular demarcation, muscle fibre surrounding the ductules got thickned. Stereocilia are almost lost.

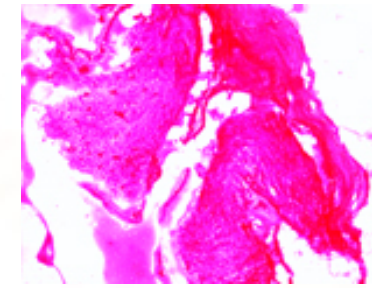

Plate\# 2c-Epididymis (Caput) $50 \mathrm{mg} / \mathrm{kg} \mathrm{b.w}$. Photomicrograph showing loss of columnar cells and basal cells and due to degeneration large vacuolar region are seen. 


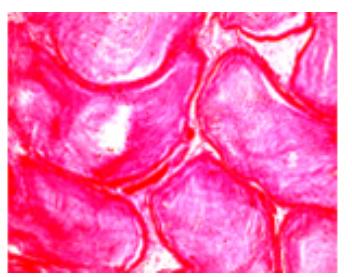

Plate\# 3 (EpididymisCauda)

Photomicrograph showing low cuboidal cells, ductule lumen smaller with intertubular connective tissues with vascularity, lumen full of spermatozoa.

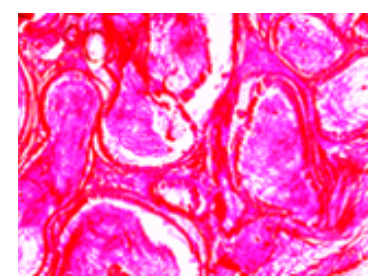

Plate\# 3a-Epididymis (Cauda) $5 \mathrm{mg} / \mathrm{kg} \mathrm{b.w.}$ Photomicrograph showing reduced epithelial cell height. Lumen of the ductules are reduced, ductules get shrinken and vacuolar region's are seen . Stereocilia are seen clustered.

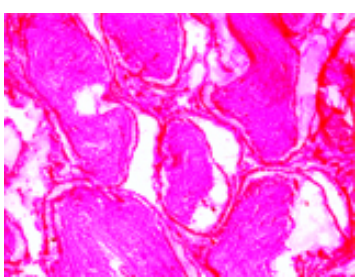

Plate\# 3b-Epididymis (Cauda) 20mg/kg b.w. Photomicrograph showing lumen of ductules reducing with columnar and basal cells mixed. Large vacuoles are seen.

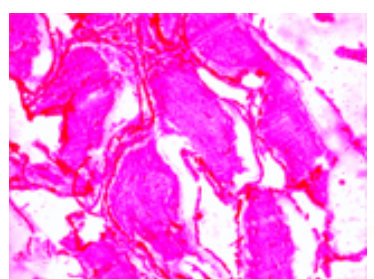

Plate\# 3c-Epididymis (Cauda) 50mg/kg b.w.

Photomicrograph showing lost stereocilia breakage of ductules valves and large spaces seen between the ductules.

\section{EXPERIMENTAL GROUPS - 60 DAYS}

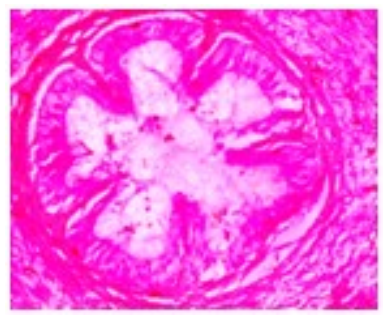

Plate\# 4 (Vas deferens)

Photomicrograph showing mucosal layer around lumen and surrounded by thick mascularis made up of inner longitudinal, middle circular and outer longitudinal muscle fibres. The mucosal cells of tall columnar cells with stereocilia, basal cells in the mucosal epithelium.
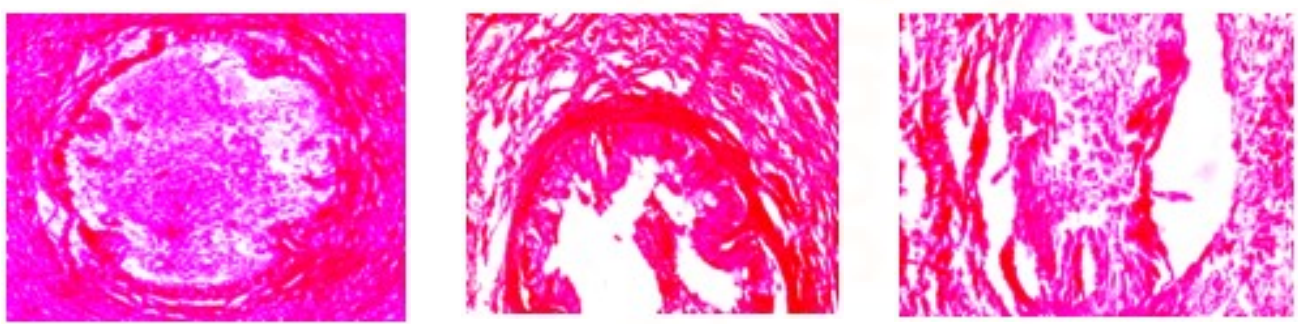

\section{Plate\# 4a - Vas}

Deferens 5mg/kg b.w

Photomicrograph showing stretched mucosal lining with effected cremaster muscle . Fibrosa is also seen reducing.
Plate\# 4b - Vas

Deferens 20mg/kg b.w

Photomicrograph showing reduced lumen loosing its shape. The mucosal lining is loosing sterocelia.
Plate\# 4c-Vas Deferens 50mg/kg b.w Photomicrograph showing lost lumen shape with disintegrated mucosal epithelium . Large vacuolar gaps are visible. 


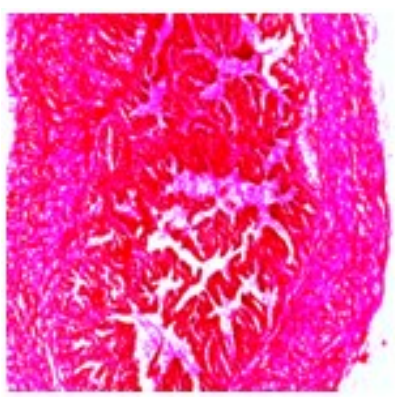

Plate\# 5 (Seminal Vesicle)

Photomicrograph

showing mucosal folds with columnar cells and basal cells. The mucosa is surrounded by inner circular and outer longitudinal muscle fibres.

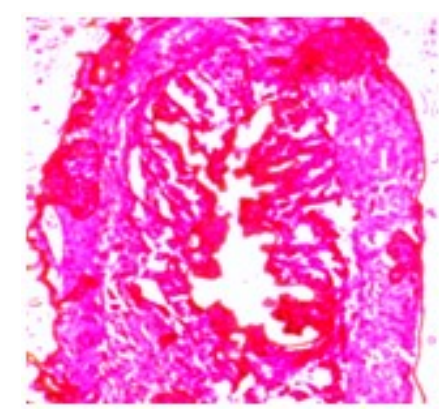

Plate\# 5a - Seminal Vesicle 5mg/kg b.w.

Photomicrograph showing numerous tall narrow and irregular folds and chambers, mucosal epithelium seems to be pseudostratified. Smooth muscles are getting deshaped.

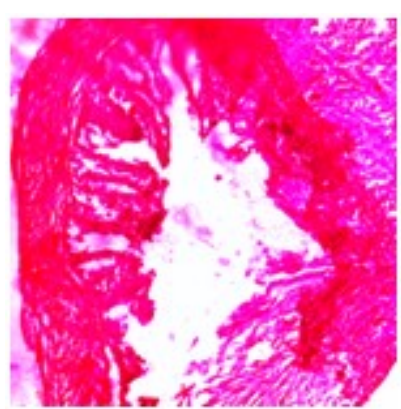

Plate\# 5b - Seminal

Vesicle $20 \mathrm{mg} / \mathrm{kg}$ b.w. Photomicrograph showing disintegrated mucosal lining, damaged columnar cells with enlarged lumen in the vesicle.

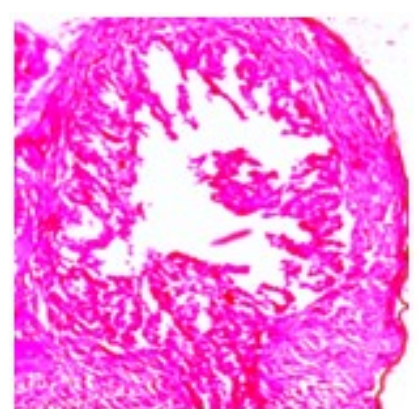

Plate\# 5c - Seminal Vesicle $50 \mathrm{mg} / \mathrm{kg} \mathrm{b.w}$. Photomicrograph showing severally damaged mucosa of the vesicle and damaged crypts with large space. Mucosal epithelium is disintegrated and the circular support is totally damaged.

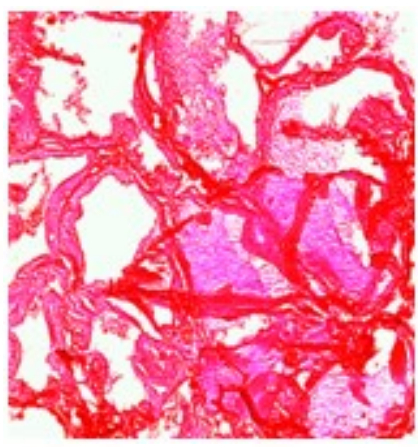

\section{Plate\# 6b-Prostate Gland $20 \mathrm{mg} / \mathrm{kg}$ b.w Photomicrograph showing reduced glandular epithelium, lumen of alveoli seen widening and a overall decline in histoarchitecture.}

Plate\# 6c - Prostate Gland 50mg/kg b.w Photomicrograph showing decline in overall histoarchitecture including lumen of the

alveoli.

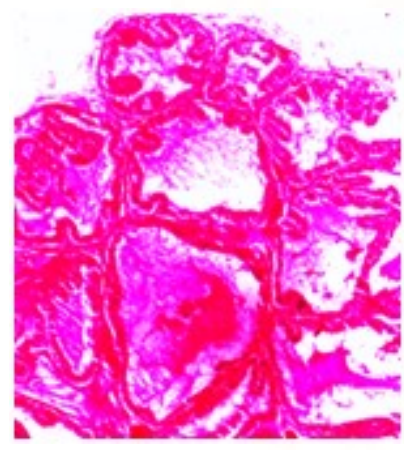

No mucosal folds.

Alveoli have

pseudostratified epithelium. The lumen

of alveoli have spherical bodies called corpora amylacea. disintegrating cellular structure around the lumen. 